\title{
EFFICIENCY IN THE SLOVAK BANKING INDUSTRY: A COMPARISON \\ OF THREE APPROACHES
}

\section{Martin Bod’a, Emília Zimková*}

\begin{abstract}
:
The paper emphasizes that any approach to defining technical efficiency in banking is just a different outlook on manifold goals and functions that commercial banks pursue. Three commonly applied approaches, i.e. the service-oriented approach, the intermediation approach and the profitoriented approach, are not in conflict but are complementary in providing information on how commercial banks perform in financial intermediation, provision of banking services and profit seeking. In addition to the methodological contribution of the paper, it investigates the efficiency of the Slovak banking industry over the years 2000-2011 so as to find whether employment of a specific approach changes the view on efficiency of individual commercial banks. To this end, the non-parametric method of evaluation is employed based on the slack-based measure model of data envelopment analysis. The results suggest that general impressions of the efficiency status of individual banks as obtained within the three approaches are similar in most cases.
\end{abstract}

Keywords: efficiency, the Slovak banking industry, SBM model, the intermediation approach, the service-oriented approach, the profit-oriented approach

JEL Classification: G21, C44

\section{Introduction}

Over recent years, the topic of measuring efficiency of commercial banks has experienced massive upheaval. Three principal approaches have been developed (to say nothing of their modifications) and are used intensively in evaluating efficiency of commercial banks. These approaches, namely the intermediation approach, the service-oriented approach and the profit-oriented approach, are described in the paper and their use is applied to the data on commercial banks in the Slovak banking industry. In this, the aim of the paper is twofold: On the one hand, the paper reconciles seemingly incompatible views of technical efficiency in banking that are represented by the three approaches, and clarifies that they are only just a different outlook on the same production technology of banking business. On the other hand, the paper investigates whether employment of a specific approach changes the view on efficiency of individual commercial banks.

* Martin Bod’a, Matej Bel University in Banská Bystrica, Faculty of Economics, Banská Bystrica, Slovakia (martin.boda@umb.sk).

Emília Zimková, Matej Bel University in Banská Bystrica, Faculty of Economics, Banská Bystrica, Slovakia (emilia.zimkova@umb.sk).

The authors extend their gratitude to Professor Emmanuel Thanassoulis of Aston Business School in Birmingham for a very careful reading of this text and for his comments. The paper is prepared in partial fulfilment of the Operational Program Education Project ITMS 26110230082 Mobility Support of Science, Research and Education at Matej Bel University in Banská Bystrica (Mobility - podpora vedy, výskumu a vzdelávania na UMB) and co-financed by the European Social Fund within the bounds of financial subsidy contract No. 018/2012/1.2/OPV. 
The motivation for this cause stems from seeming discordance of the three approaches as to understanding the primary role of banks and the character of their efficiencies and/ or inefficiencies. The common trait of the approaches is that each of them necessitates the assumption that there exists a production function in the banking industry (which links the inputs and outputs of banks and determines the shape of the production possibility set). Yet, differences between the said approaches are not related to the functional form of the production function itself (as in fact they do not go into a specification of the production function) but arise in the definition of the raison d'être of commercial banks. These differences are then reflected in the selection of inputs and outputs on the scale of which efficiency is measured and evaluated. Therefore, it is only natural that the results obtained by an application of respective approaches may and do differ. Other factors that affect the practical use of these approaches are the choice of method for its estimation and the character of operations determining banking production (i.e. returns to scale in the banking sector).

In the paper, the non-parametric slack-based measure (SBM) model is applied with each of the three generic approaches of interpreting bank's efficiency and results are compared in order to find whether there are substantive differences between these three approaches when applied in practice. Each approach is pinpointed in the paper with the underlying perspective which is its philosophical cornerstone and which allows an economic interpretation of the findings. Whereas the intermediation approach considers the commercial bank as a financial intermediary and is thus consistent with the macroeconomic view of commercial banks, the service-oriented approach takes the commercial bank to be a service producer aiming at minimizing operating costs and explains the behaviour of commercial banks from the microeconomic standpoint. Eventually, the profit-oriented approach treats the commercial bank as a profit-maximizing firm whose depository and intermediatory functions are only instrumental in achieving the primary goal of profit maximization. As the interpretation of banking behaviour differs across the three approaches, it is only reasonable that their evaluation of banking performance in terms of efficiency might yield a different assessment with each approach.

To this end, a data set of eleven commercial banks of the Slovak banking industry for the period of the years 2000-2011 was available for the analysis. During this period, the Slovak banking sector has gone through some changes regarding its structure, competitiveness and regulation. Nonetheless, three periodization landmarks were identified and catalogued, between which it is assumed that the production function did not change and remained intact, i.e. was invariant with respect to a time shift. These landmarks divided the entire period of twelve years into three sub-periods, over which the data on individual commercial banks of the Slovak banking industry were pooled for their joint evaluation. In each sub-period, individual commercial banks were evaluated and their efficiency was determined by the slack-based measure. These results permitted a comparison of the three approaches.

Unsurprisingly, it was found that the choice of the philosophical standpoint expressed in individual approaches is an influential factor in the process of efficiency evaluation. As indicated before and explained later in the paper, this is in accord with the distinctions in the fundamental treatment of banking behaviour with the three approaches. Neglecting that each approach corresponds to a different view of the same production technology of commercial banks, the evaluations of commercial banks with individual approaches are 
positively correlated and especially the intermediation approach and the service-oriented approach share a certain degree of similarity. The same holds for the service-oriented approach and the profit-oriented approach.

The paper is organized in 6 sections, the first of which is introductory and the last is concluding. The second section explains the concepts developed in the literature for measuring efficiency of commercial banks. In addition to that, it provides an overview of some relevant studies on the topic. The third methodological section is accompanied by the fourth and the fifth sections which present the results and discuss their interpretation.

\section{Conceptual Issues to Interpreting Efficiency of Commercial Banks and Overview of Literature}

Conceptual views of efficiency of commercial banks differ. Individual theoretical concepts concur that commercial banks are agents of a transformation process and that during this process they transmute a set of inputs into a set of outputs. These inputs and outputs are linked in operations of commercial banks through a production function, which specifies the maximum attainable outputs at the given level of inputs. On the one hand, there is an explicit or implicit agreement that such a functional relationship exists; on the other hand, there is no general agreement on the production function of commercial banks which would reflect the aims that commercial banks seek to pursue.

So far three main approaches have been developed and used both in theory and practice. The primary source of difference between them is the treatment of deposits, which have both input and output characteristics. Each of these approaches is clarified in next paragraphs.

The first approach is called the production approach, which goes in two variants known as the service-oriented approach and the user-cost approach. The production approach views deposits as outputs. It assumes that the aim of commercial banks is to produce deposits (liabilities) as well as loans (assets) and other services. One of the first studies under this approach was Benston (1965). The variant of this approach that considers deposits to be an output together with loans and the interest income is called the service-oriented approach. A modification of the production approach is also the usercosts approach developed by Hancock (1991). In this case deposits are specified as both inputs and outputs of the cost/profit function of a commercial bank.

The second approach, the intermediation approach, interprets deposits as inputs. It was introduced and published by Sealey and Lindley (1977). The intermediation approach assumes that the main aim of a commercial bank is to create output, defined as loans and investment, whilst using liabilities (including deposits), labour, and capital as inputs. In the underlying philosophy of this approach a commercial bank is a chief financial intermediary in economy and its primary role is to transmute deposits into loans, which pre-determines the treatment of deposits as inputs and loans as outputs.

The newest approach - the profit-oriented approach is an elaboration of the intermediation approach. Whilst the original intermediation approach itself is assetoriented as it confronts balance-sheet intermediation inputs and intermediation outputs, this is modified within this approach as the profit-maximizing tendency of commercial banks (still financial intermediaries) is emphasized. Singling out the commercial bank as a profit-maximizing firm, the profit-oriented approach attempts to capture final monetary effects of financial intermediation, in which interest expenses and/or non-interest expenses 
are found as inputs and interest income and/or non-interest income are used as outputs. Such a specification retains the minimizing feature of inputs and the maximizing feature of outputs and resolves the problem with designating deposits either as an input or as an output. This approach is singled out by Kamecka (2010, pp. 37-40) and justified in Ahn and Le (2014, pp. 19-20).

For the sake of completeness, it need be stated that the foregoing research on banking behaviour was the value-added approach, which considers that both liability and assets categories possess some output characteristics. Only those categories which contribute to a substantial value added are treated as outputs whilst the others are treated as either inputs or intermediate products depending on the specific attributes of each category. This approach was promoted by Berger, Hanweck, and Humphrey (1987), and Berger and Humphrey (1997). This approach is not pursued in the paper since its application would require a more sensitive analysis of individual processes that are carried out by the commercial banks under evaluation.

As stated above, various concepts to efficiency of commercial banks favour the use of different inputs and outputs. The most commonly used approach in the banking industry is probably the intermediation approach (see e.g. Ahn and Le, 2014, pp. 9, 18). In the published studies applying even the same approach, different inputs and outputs can be recognized, which is taken advisement in the building of the methodological part of the paper.

There has been intensive research on measuring efficiency of commercial banks and their benchmarking. It is probably not possible to give an exhaustive overview of the relevant literature on this topic. In consequence of this, the scope of the presentation here is limited only to the research that focussed on the so-called Visegrad Group countries (the Czech Republic, Poland, Hungary and the Slovak Republic) and utilized the non-parametric approach of the data envelopment analysis (DEA). Table 1 summarizes empirical studies that are germane to this topic and lists especially those studies that have applied the non-parametric approach based on a DEA model. The list of research works is structured into two categories: cross-country studies (which investigated the efficiency of commercial banks across several countries for the purpose of comparison) and single market studies (which focused on the efficiency of commercial banks in one country only).

Table 1 | Empirical Studies Grouped by the Visegrad Group Coverage (in the alphabetical order)

\begin{tabular}{|l|l|}
\hline Cross-country studies & DEA methodology \\
\hline Grigorian and Manole (2002) & CCR, BCC \\
\hline Kenjegalieva et al. (2009) & BCC \\
\hline Stavárek (2006) & CCR, BCC \\
\hline Tomova (2006) & BCC \\
\hline Vincová (2006) & CCR, BCC \\
\hline Single market studies & DEA methodology \\
\hline Stavárek and Řepková (2012) & CCR, BCC \\
\hline Wozniewska (2008) & CCR, BCC \\
\hline Zemanová (2007) & CCR \\
\hline
\end{tabular}

Source: the authors 
Although the majority of the studies (amongst the cited authors: Grigorian and Manole, 2002; Tomova, 2006; Řepková and Stavárek, 2012; Kenjegalieva et al., 2009) fell back upon both nonparametric and parametric techniques to evaluate the bank performance in terms of efficiency, all of the studies that are listed in Table 1 utilized in their quest only basic and rudimentary DEA models, the model by Charnes, Cooper and Rhodes (1978) addressed conventionally as the CCR model and the model by Banker, Charnes and Cooper (1984) addressed conventionally as the BCC model. In this paper, the model by Tone (2001), a more advanced DEA model, is utilized and this model is usually called the SBM (slack-based measure) model.

\section{Methodology}

The exposition of the previous section indicated the existence of various streams in comprehending and interpreting the performance of commercial banks. From the pure theoretical viewpoint, they differ considerably, but there is still a curious question whether there is a weighty difference between these approaches in practical applications. Obviously, it is of interest to investigate as to whether it really depends on the choice of a particular approach (i.e. the production approach, the intermediation approach and the profit-oriented approach) in the benchmarking of commercial banks and in the assessing of their performance in terms of efficiency and their management of available resources. This study, motivated hereby, seeks to find whether these approaches, so much distinctive in their concept may be reconciled or whether they lead to different conclusions on efficiency.

In order to demonstrate how the selection of a respective approach may influence the obtained results, for each of the three sub-periods and under each of the three approaches, the SBM analysis was applied on the panel data of eleven commercial banks of the Slovak banking sector during the period from 2000 to 2011. (This data span is chosen in regard to the data availability and currency for the needs of this analysis.) The methodological procedure stands on several characteristic points or assumptions that underlie and shape the line of research and they are summarized and explained in brief in the following text.

\section{The assumption of the production frontier time invariance during three identified phases of the Slovak banking sector development}

Every sensible and interpretable application of the DEA rests on the explicit assumption of the existence of a production frontier that delimits the set of all disposable inputs and attainable outputs. The optimization task of a chosen DEA model then constructs in a non-parametric fashion the production frontier and measures in an appropriate way the distance of individual production units from the production frontier and captures it in the form of a score (used in assessing the relative efficiency of a given production unit and in the benchmarking). However, it often happens that the production frontier changes over time (even this change is required for the theory of economic growth to be valid and hold). Though this being true, in some consecutive periods the production frontier due to the inertia of the economic environment may remain invariant, that is invariant with respect to a time shift. This view is applied in the paper and it is believed that there are some phases in the evolution of the Slovak banking sector during which its production frontier remained intact and free of shift. During the period from 2000 to 2011, three sub-periods can be identified and justified: 2000-2003, 2004-2008, 2009-2011. 
- The first phase (2000 to 2003) reflects the last quivers of the restructuring of major banks and of the privatization of selected banks in Slovakia that commenced in the 1990s. Whereas political decisions on the transfer of illiquid assets into a specialized state institution were taken in the second half of the 1990s and the transfer itself took place especially in the years 1998 and 1999, the cleaning-up of balance sheets of the Slovak major banks ended only at the beginning of the 2000s. This phase was also accompanied by final stages of the transformation process of the Slovak economy.

- The second phase (2004-2008) begins by the accession of Slovakia into the European Union and terminates by the entry of Slovakia into the euro area. Slovak banks during this period implemented a new system of corporate governance, moved to the communication with targeted client segments and towards electronic banking services. There were significant changes in balance sheet and off-balance sheet operations, in the structure of services and in the orientation on investment banking, mortgage banking as well as asset management.

- $\quad$ The third phase (2009-2011) is marked by the successful adaptation of the Slovak banking sector to the euro environment and by the manifestations of the economic crisis in the Slovak economy. On the other hand, of impact on the Slovak banking sector was the global economic crises that brought about a dramatic fall in the economic growth of Slovakia. Small Slovak banks faced existence problems.

\section{The selection of commercial banks of the Slovak banking sector and the selection of a particular set of inputs and outputs with each approach}

The dataset comprises the data on 11 commercial banks (commercial banks) operating in the Slovak Republic and it covers the great majority of Slovak banking structures (as the total of included banks exceeds 90 per cent of the Slovak banking assets). The commercial banks considered in the paper are listed in Table 2. The source of the data is TREND Holding, s.r.o., Bratislava.

Table 2 | Commercial Banks of the Slovak Banking Sector Subjected to the Analysis

\begin{tabular}{|l|l|}
\hline Commercial bank \\
\hline Citibank Europe plc, foreign bank subsidiary (before 2009 Citibank (Slovakia), a. s.) \\
\hline Československá obchodná banka, a. s. (in 2009 merged with Istrobanka, a. s.) \\
\hline Prima banka Slovensko, a. s. (before 2011: Dexia banka Slovensko, a. s.) \\
\hline Privatbanka, a.s. (before 2005 Banka Slovakia, a. s.) \\
\hline OTP Banka Slovensko, a. s. & Poštová banka, a.s. \\
\hline Slovenská sporitelňa, a. s. & Tatra banka, a.s. \\
\hline VOLKSBANK Slovensko, a. s. (since 2013 Sberbank Slovensko, a. s.) \\
\hline Všeobecná úverová banka, a. s. \\
\hline UniCredit Bank Slovakia, a. s. (a 2007 merger of UniBanka, a. s. \& HVB Bank Slovakia, a. s.) \\
\hline
\end{tabular}

Source: the authors 
The data used in the empirical analysis are the yearly data of balance-sheet items disclosed by the eleven commercial banks of the Slovak banking sector during the period 2000-2011. During the period some of the commercial banks underwent a merger or a takeover, it was therefore necessary to operate with totals on the banks which changed its legal and economic status. The data on these banks were aggregated as a total and only the merger or the acquisitor is considered. The hypothesis on the time-invariance of the production function permitted the pooling of individual commercial banks in the identified phases and resulted in "bank-years". Only the data for 4 bank-years were not complete (ČSOB / Istrobanka 2007 \& Citibank 2009, 2010, 2011). In consequence, the first phase was represented by 44 bank-years, the second phase included 54 bank-years, and finally, the third phase was formed by 41 available bank-years. The data are evaluated within the framework of the DEA separately. The pooling of the data from different years necessitated their deflation for a proper analysis. Individual balance-sheet and incomestatement items were deflated to the prices of 2000 by the GDP deflator provided by Eurostat. An overview of inputs and outputs that were recognized with each approach is given in Table 3 .

Table 3 | Inputs and Outputs Used with Each of the Three Approaches

\begin{tabular}{|c|c|c|c|}
\hline & $\begin{array}{l}\text { Intermediation } \\
\text { approach }\end{array}$ & $\begin{array}{l}\text { Service-oriented } \\
\text { approach }\end{array}$ & $\begin{array}{l}\text { Profit-oriented } \\
\text { approach }\end{array}$ \\
\hline Inputs & $\begin{array}{l}\text { total deposits } \\
\text { capital total } \\
\text { operating expense }\end{array}$ & $\begin{array}{l}\text { capital total } \\
\text { operating expense }\end{array}$ & total operating expense \\
\hline Outputs & $\begin{array}{l}\text { total loans net } \\
\text { interest income }\end{array}$ & $\begin{array}{l}\text { total deposits total } \\
\text { loans net interest } \\
\text { income }\end{array}$ & net interest income \\
\hline
\end{tabular}

Source: the authors

\section{The Employment of the SBM Model}

In this paper, the assumption of variable returns to scale is formed (which, of course includes a specific case of constant returns to scale) and combined with a non-oriented SBM model in evaluating the commercial banks of the Slovak banking sector on a comparative basis. Note that the studies enumerated earlier used in their analysis the rudimentary CCR or BCC model. Ahn and Le (2014, p. 15) call these models as "the standard DEA models" utilized in DEA-based bank efficiency studies. They use the adjective "standard" in the sense of being basic and elementary. This study thus goes farther as it employs a conceptually simple and sound, yet more precise DEA model.

In the exact formulation of the SBM model, it is assumed that the data on $n$ production units are available, where any production unit $o, o \in\{1, \ldots, n\}$ produces $s$ desirable outputs out of $m$ inputs. The values of inputs of production unit $o$ are represented by vector $\mathbf{x}_{o}=\left(x_{o 1}, \ldots, x_{o m}\right)^{\prime}$ and the values of outputs by vector $\mathbf{y}_{o}=\left(y_{o 1}, \ldots, y_{o s}\right)^{\prime}$. The elements of both vectors are positive. Individual inputs and outputs have corresponding vectors of potential slacks $\mathbf{s}^{\mathbf{x}}=\left(s_{o 1}^{\mathbf{x}}, \ldots, s_{o m}^{\mathbf{x}}\right)^{\prime}$ and $\mathbf{s}_{o}^{\mathbf{y}}=\left(s_{o 1}^{\mathbf{y}}, \ldots, s_{o s}^{\mathbf{y}}\right)^{\prime}$, which states how individual 
inputs and outputs must be improved in order that production unit $o$ become efficient (whereas vector of inputs $\mathbf{x}_{o}$ need be reduced by $\mathbf{s}^{\mathbf{x}}{ }_{o}$ and vector of outputs $\mathbf{y}_{o}$ need be increased by $\mathbf{s}^{\mathbf{y}}{ }_{0}$ ). These slacks are to be identified by the DEA and serve as an exclusive basis of efficiency calculation for respective production unit $o$.

For each production unit $o, o \in\{1, \ldots, n\}$, it is necessary to solve the following task of linear programming of the non-oriented SBM model under the assumption of variable returns to scale,

$$
\begin{array}{r}
\rho_{o}\left(\lambda, \mathbf{s}^{\mathbf{x}}, \mathbf{s}^{\mathbf{y}}\right)=\frac{1-\frac{1}{m} \sum_{i=1}^{i=m} s_{o i}^{\mathbf{x}} / x_{o i}}{1+\frac{1}{s} \sum_{j=1}^{j=s} s_{o j}^{\mathbf{y}} / y_{o j}}=! \min \\
\mathbf{s}^{\mathbf{x}}=\mathbf{x}_{o}-\sum_{i=1}^{i=n}\{\boldsymbol{\lambda}\}_{i} \mathbf{x}_{i} \geq \mathbf{0} \\
\text { with respect to } \quad \mathbf{s}^{\mathbf{y}}=\mathbf{y}_{o}-\sum_{i=1}^{i=n}\{\boldsymbol{\lambda}\}_{i} \mathbf{y}_{i} \geq \mathbf{0} \\
\sum_{i=1}^{i=n}\{\boldsymbol{\lambda}\}_{i}=1, \boldsymbol{\lambda} \geq \mathbf{0}
\end{array}
$$

The symbol " $\geq$ " denotes at a vector that respective elements of this vector are non-negative and at least one element is non-zero.

The restrictions of the optimization task constructs the production possibility set with respect to $n$ production units and their observed inputs $\mathbf{x}_{1}, \ldots, \mathbf{x}_{n}$ and outputs $\mathbf{y}_{1}, \ldots, \mathbf{y}_{n}$ as well as their convex linear combinations in $\mathrm{R}^{m}$ and $\mathrm{R}^{s}$, respectively. The coefficient $\rho$ takes values at interval $[0,1]$ and it is the SBM score of technical efficiency (in this case of production unit $o$ whose task (1) is subject to optimization. If for some production unit $\rho=1$ happens to be the case, this production unit is called SBM-efficient, which means that it is technically efficient in the sample of $n$ production units to be evaluated.

There are certain economic assumptions associated with this procedure. First of all, it is required that the unobservable production function is well-behaved and that production units operate with homogeneous inputs and outputs at (possibly) variable returns to scale. Under this set-up, the production function is approximated within the DEA framework by a piecewise linear convex production possibility set. In this, no specific functional form of production function is assumed and no statistical assumptions are prerequisite. The absence of statistical assumptions contrasts with the parametric framework of econometric stochastic frontier analysis (SFA), whose usage requires the specification of three crucial ingredients: the functional form of production function, the probability distribution of inefficiency and the probability distribution of measurement errors. These desiderata complicate the analysis as the spectrum of all possibilities is broad, and - as a matter of fact - practicable SFA models are few. This suggests a chance of an erroneous specification and wrong conclusions. On the other hand, DEA models in their pure form rely heavily on the accuracy of the data and make no allowance for possible measurement errors. In addition, of a small economic limitation there is the implicit assumption that in the analysed set of production units at least one production unit is technically efficient, which permits the correct identification of the production possibility set.

In the paper, the role of production units is undertook by individual commercial banks in the Slovak banking sector in the three phases of its development. 


\section{Results}

All computations were performed in program R (R Core Team, 2013) by means of functionalities included in package nonparaeff (Oh and Suh, 2013). The results are displayed compactly in Table 4; which presents the information on the achieved SBM score for each commercial bank of the Slovak banking sector in each phase. In the table, a substitutionary notation is utilized and for the sake of economy it is adopted in the further text, IA standing for (the) intermediation approach, SOA representing (the) service-oriented approach, and - finally - PA denoting (the) profit-approach. NA signifies that the data for the respective bank and for the respective sub-period were not available. The (simplifying if understandable) designations of individual commercial banks indicated in the table are also used in the interpretations.

Comparing the results of individual approaches, on first inspection, it is clear that there are detectable and manifest differences between the approaches, and it is especially the PA which differs in the SBM scores substantially from both the IA and the SOA as its scores are in most cases lower in the third sub-period and reverse in the other two sub-periods. The application of the IA and the SOA across individual sub-periods thus lead to more homogeneous SBM scores in comparison to the PA. Besides the sheer economic reasons, these results are most probably influenced by a different number of analysed inputs and outputs with each theoretical approach entertained.

Table 4 | Results of the Application of the SBM Model in the Individual Phases

\begin{tabular}{|c|c|c|c|c|c|c|c|c|c|c|}
\hline \multirow{2}{*}{$\begin{array}{l}\text { Commercial } \\
\text { bank }\end{array}$} & \multirow{2}{*}{ YEAR } & \multicolumn{3}{|c|}{ THE FIRST PHASE } & \multicolumn{3}{|c|}{ THE SECOND PHASE } & \multicolumn{3}{|c|}{ THE THIRD PHASE } \\
\hline & & IA & SOA & PA & IA & SOA & PA & IA & SOA & PA \\
\hline \multirow{5}{*}{ Citibank } & 2000 & 0.772 & 0.649 & 0.694 & 1 & 1 & 0.778 & NA & NA & NA \\
\hline & 2001 & 1 & 0.741 & 0.848 & 1 & 0.528 & 0.596 & NA & NA & NA \\
\hline & 2002 & 1 & 1 & 0.907 & 1 & 1 & 0.552 & NA & NA & NA \\
\hline & 2003 & 1 & 1 & 0.687 & 0.713 & 0.606 & 0.669 & --- & --- & --- \\
\hline & -- & -- & -- & -- & 0.718 & 0.645 & 0.856 & --- & -- & -- \\
\hline \multirow{5}{*}{$\begin{array}{l}\text { ČSOB / } \\
\text { Istrobanka }\end{array}$} & 2000 & 0.743 & 1 & 0.929 & 0.755 & 0.735 & 0.744 & 0.766 & 0.713 & 0.602 \\
\hline & 2001 & 0.809 & 1 & 0.755 & 0.619 & 1 & 0.452 & 0.708 & 0.673 & 0.512 \\
\hline & 2002 & 0.684 & 0.756 & 0.655 & 0.898 & 0.892 & 0.623 & 0.777 & 0.653 & 0.467 \\
\hline & 2003 & 1 & 1 & 0.886 & 0.679 & 0.618 & 0.769 & --- & --- & --- \\
\hline & --- & --- & --- & --- & NA & NA & NA & --- & --- & --- \\
\hline \multirow{5}{*}{$\begin{array}{l}\text { OTP Banka } \\
\text { Slovensko }\end{array}$} & 2000 & 1 & 1 & 0.151 & 0.746 & 0.585 & 0.594 & 1 & 0.752 & 0.483 \\
\hline & 2001 & 0.824 & 0.524 & 0.475 & 1 & 0.667 & 0.644 & 1 & 0.794 & 0.486 \\
\hline & 2002 & 0.682 & 0.426 & 0.41 & 0.847 & 0.661 & 0.727 & 0.948 & 0.742 & 0.468 \\
\hline & 2003 & 0.772 & 0.557 & 0.496 & 0.964 & 0.655 & 0.723 & --- & --- & --- \\
\hline & -- & --- & --- & --- & 1 & 0.735 & 0.768 & --- & --- & --- \\
\hline \multirow{5}{*}{$\begin{array}{l}\text { Poštová } \\
\text { banka }\end{array}$} & 2000 & 0.415 & 0.439 & 0.357 & 0.395 & 0.339 & 0.656 & 1 & 1 & 0.628 \\
\hline & 2001 & 0.514 & 0.501 & 0.379 & 0.362 & 0.285 & 0.462 & 1 & 1 & 0.74 \\
\hline & 2002 & 0.513 & 0.502 & 0.665 & 0.464 & 0.356 & 0.671 & 1 & 1 & 1 \\
\hline & 2003 & 0.522 & 0.487 & 0.533 & 0.512 & 0.398 & 0.776 & --- & --- & --- \\
\hline & --- & --- & --- & --- & 0.699 & 0.542 & 0.841 & --- & --- & --- \\
\hline
\end{tabular}




\begin{tabular}{|c|c|c|c|c|c|c|c|c|c|c|}
\hline \multirow{5}{*}{ Prima banka } & 2000 & 0.781 & 0.722 & 0.889 & 0.81 & 0.816 & 0.808 & 0.837 & 1 & 0.341 \\
\hline & 2001 & 0.793 & 0.838 & 0.836 & 0.809 & 0.779 & 0.626 & 1 & 1 & 0.357 \\
\hline & 2002 & 1 & 1 & 1 & 1 & 1 & 0.882 & 0.816 & 0.874 & 0.384 \\
\hline & 2003 & 0.958 & 0.881 & 0.85 & 0.953 & 1 & 0.853 & --- & --- & --- \\
\hline & --- & --- & --- & --- & 1 & 1 & 0.817 & --- & --- & --- \\
\hline \multirow{5}{*}{ Privat banka } & 2000 & 0.854 & 0.691 & 0.931 & 1 & 1 & 1 & 1 & 1 & 1 \\
\hline & 2001 & 0.959 & 0.858 & 0.767 & 0.76 & 0.639 & 0.752 & 0.847 & 0.934 & 0.674 \\
\hline & 2002 & 1 & 1 & 1 & 1 & 1 & 0.966 & 0.878 & 1 & 0.727 \\
\hline & 2003 & 1 & 1 & 0.918 & 1 & 1 & 0.869 & --- & --- & --- \\
\hline & --- & --- & --- & --- & 1 & 1 & 1 & --- & --- & --- \\
\hline \multirow{5}{*}{$\begin{array}{l}\text { Slovenská } \\
\text { sporitelňa }\end{array}$} & 2000 & 1 & 1 & 0.826 & 0.558 & 0.626 & 0.798 & 1 & 1 & 0.797 \\
\hline & 2001 & 0.517 & 1 & 0.829 & 0.736 & 0.765 & 0.77 & 1 & 1 & 0.988 \\
\hline & 2002 & 1 & 1 & 1 & 0.867 & 1 & 0.871 & 1 & 1 & 1 \\
\hline & 2003 & 1 & 1 & 0.939 & 1 & 1 & 0.979 & --- & --- & --- \\
\hline & --- & --- & --- & --- & 1 & 1 & 1 & --- & --- & --- \\
\hline \multirow{5}{*}{ Tatra banka } & 2000 & 1 & 1 & 1 & 0.764 & 0.782 & 0.817 & 1 & 1 & 0.573 \\
\hline & 2001 & 0.852 & 0.883 & 0.79 & 0.773 & 0.814 & 0.754 & 0.811 & 0.839 & 0.617 \\
\hline & 2002 & 1 & 1 & 1 & 0.833 & 0.895 & 0.744 & 1 & 0.82 & 0.673 \\
\hline & 2003 & 0.807 & 0.799 & 0.735 & 0.908 & 0.932 & 0.681 & --- & --- & --- \\
\hline & --- & -- & -- & --- & 1 & 1 & 0.708 & --- & --- & -- \\
\hline \multirow{5}{*}{$\begin{array}{l}\text { UniCredit } \\
\text { Bank }\end{array}$} & 2000 & 0.878 & 0.654 & 0.744 & 0.675 & 0.674 & 0.749 & 0.907 & 0.689 & 0.401 \\
\hline & 2001 & 0.815 & 0.671 & 0.7 & 0.719 & 0.642 & 0.622 & 0.859 & 1 & 0.401 \\
\hline & 2002 & 1 & 1 & 0.967 & 1 & 0.776 & 0.878 & 1 & 1 & 0.452 \\
\hline & 2003 & 1 & 1 & 0.657 & 1 & 1 & 0.873 & --- & --- & --- \\
\hline & --- & -- & --- & --- & 1 & 0.804 & 0.894 & --- & --- & -- \\
\hline \multirow{5}{*}{$\begin{array}{l}\text { VOLKSBANK } \\
\text { Slovensko }\end{array}$} & 2000 & 0.638 & 0.651 & 0.705 & 0.644 & 0.473 & 0.649 & 1 & 0.575 & 0.351 \\
\hline & 2001 & 0.611 & 0.624 & 0.633 & 0.665 & 0.496 & 0.654 & 0.875 & 0.645 & 0.398 \\
\hline & 2002 & 0.7 & 0.561 & 0.687 & 0.721 & 0.556 & 0.711 & 0.824 & 0.674 & 0.388 \\
\hline & 2003 & 0.718 & 0.552 & 0.685 & 0.732 & 0.553 & 0.653 & --- & --- & --- \\
\hline & --- & -- & --- & --- & 0.771 & 0.598 & 0.714 & --- & --- & --- \\
\hline \multirow{5}{*}{$\begin{array}{l}\text { Všeobecná } \\
\text { úverová } \\
\text { banka }\end{array}$} & 2000 & 1 & 1 & 0.704 & 0.644 & 0.719 & 0.878 & 0.905 & 1 & 0.853 \\
\hline & 2001 & 0.639 & 0.635 & 0.831 & 0.707 & 0.724 & 0.849 & 0.914 & 1 & 0.901 \\
\hline & 2002 & 0.601 & 0.595 & 0.799 & 0.716 & 0.774 & 0.848 & 1 & 1 & 0.94 \\
\hline & 2003 & 0.676 & 0.664 & 0.855 & 0.884 & 0.873 & 0.931 & --- & --- & -- \\
\hline & --- & --- & --- & --- & 1 & 1 & 1 & --- & --- & --- \\
\hline
\end{tabular}

Notes: "IA" abbreviates the intermediation approach, "SOA" denotes the service-oriented approach and "PA" stands for the profit-oriented approach.

Source: the authors

Figure 1 provides a good visualization of SBM technical efficiency scores in the form of 9 boxplots for each of the three approaches in each of the three sub-periods. It follows clearly from the bold-line position of medians that, in general, the PA delivers a comparatively lower efficiency scores than the other two approaches. Another interesting fact is that, in the first sub-period and the third sub-period, the number of full technical 
efficiencies (i.e. bank-years identified at their full efficiency) recognized with the SOA is not lower than $50 \%$. Moreover, SBM scores found with the PA are even distributed more uniform or symmetrically that with the other two approaches.

Figure 1 | Comparison of SBM Technical Efficiency Scores in Individual Approaches
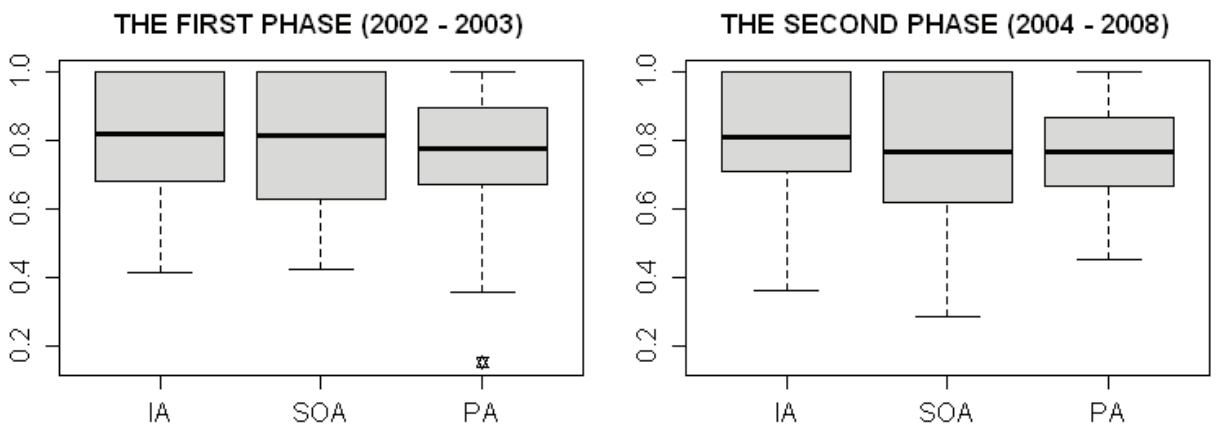

THE THIRD PHASE (2009 - 2011)

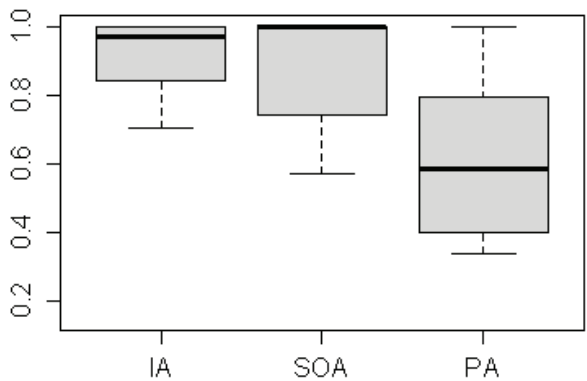

Notes: "IA" abbreviates the intermediation approach, "SOA" denotes the service-oriented approach and "PA" stands for the profit-oriented approach.

Source: the authors

Figure 2 is assistant in evaluating the concordance between the individual approaches in terms of SBM efficiency scores. The upper right triangle is a traditional scatter matrix of individual SBM scores with the IA, SOA, and PA and the bold line represents a smoothed version of the regression line obtained by means of the LOWESS algorithm. The lower left triangle presents the values of the corresponding Spearman correlation coefficient (with height scaled by its value) and the corresponding 0.95 bootstrap confidence interval constructed by the percentile method based on 5,000 bootstrap replications. Note that the computed confidence intervals are only approximate as their rigorous treatment requires that the data analysed be a random sample, which is obviously not the case. 
Figure 2 | Relationships between SBM Technical Efficiency Scores in Individual Approaches

THE FIRST PHASE (2000 - 2003)

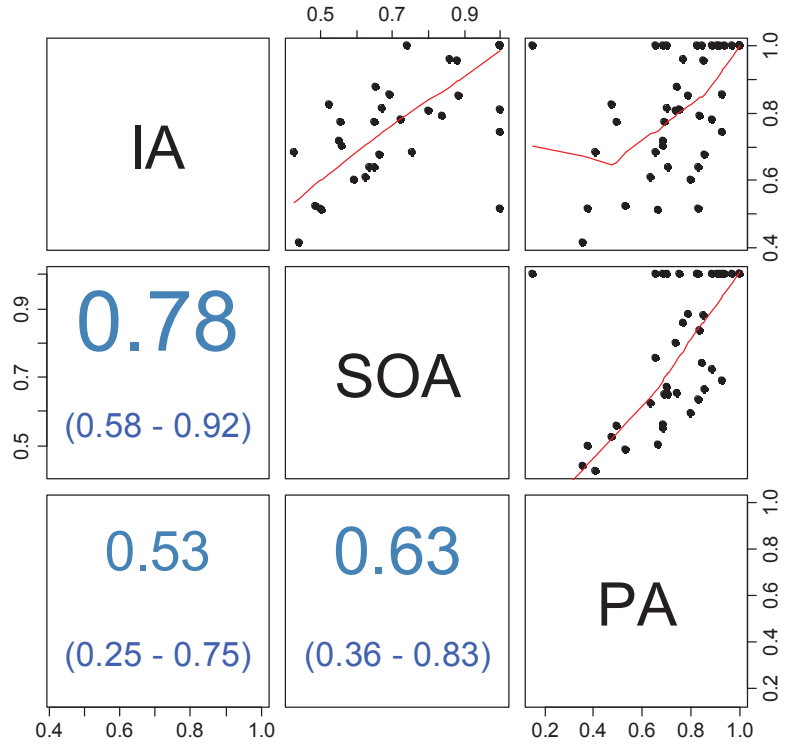

THE SECOND PHASE (2004 - 2008)

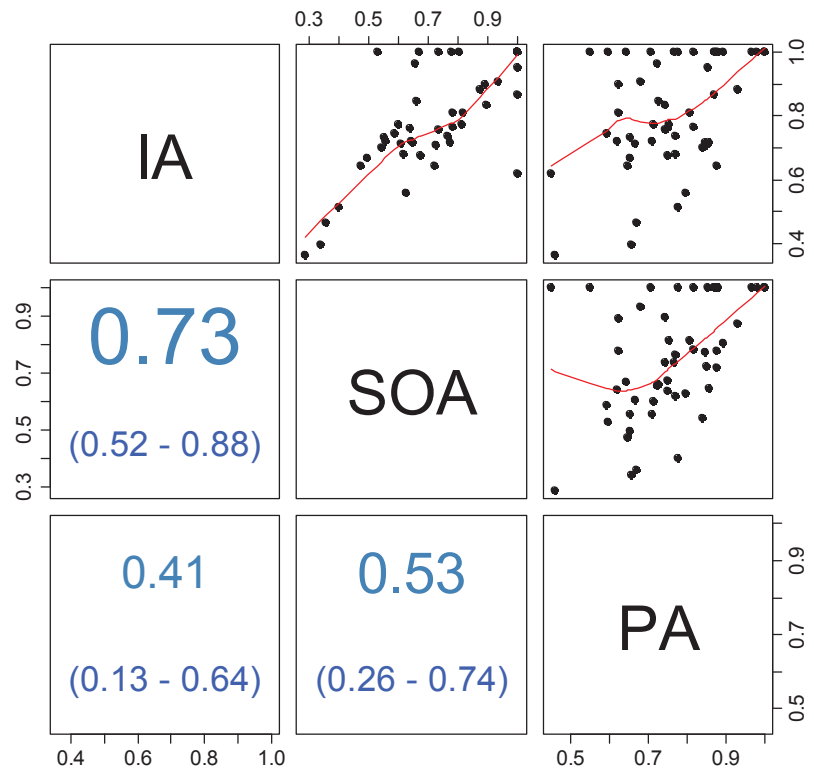


THE THIRD PHASE (2009 - 2011)
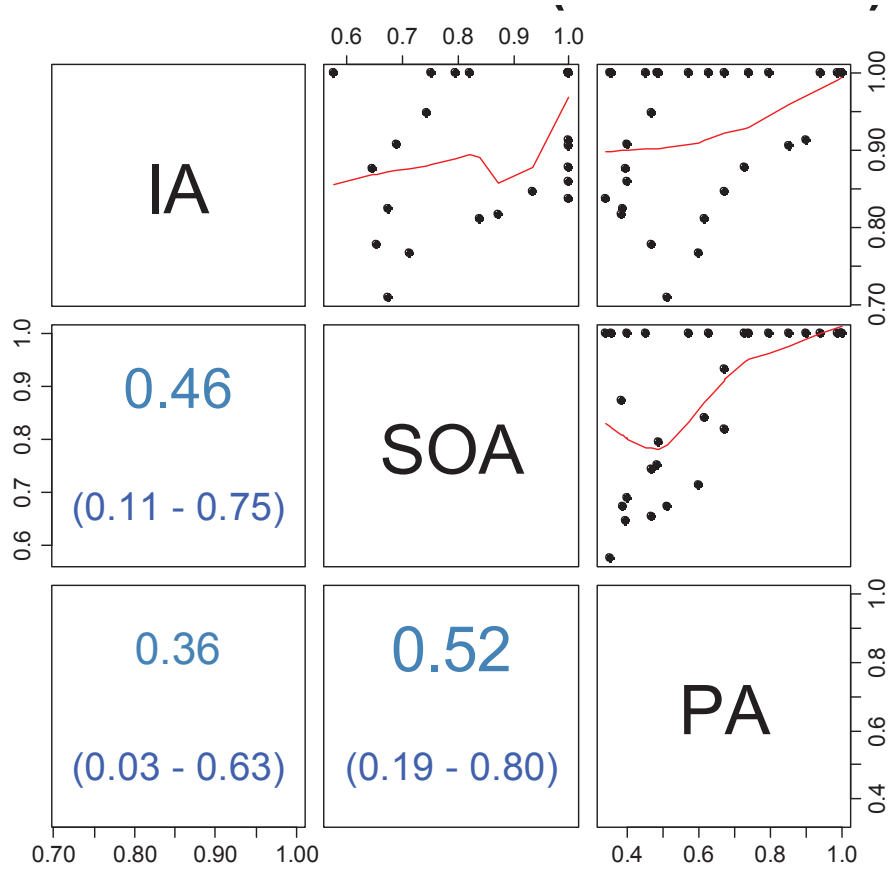

Notes: "IA" abbreviates the intermediation approach, "SOA" denotes the service-oriented approach and "PA" stands for the profit-oriented approach. In the upper right triangle of the scatter matrix, the LOWESS line is plotted through SBM efficiency scores for individual approaches, and in the lower left triangle, associated Spearman correlations with approximate 0.95 bootstrap confidence intervals are shown.

Source: the authors

SBM scores in each sub-period identified with individual approaches are all positively correlated as is suggestive not only by the point estimates of correlation coefficients themselves but also by their confidence intervals. The most tight relationship is ascertained in the first two sub-periods between the IA and the SOA and in the third sub-period between the SOA and the PA. In addition, another strong positive relationship is found in the first sub-period between the SOA and the PA. It goes without saying, the stronger the relationship between SBM scores found with individual approaches, the higher similarity of these approaches as to their perspective on technical efficiency of commercial banks under analysis.

As follows from the ensuing discussion, this similarity is implied by the fact that if a bank is outstanding from one view of technical efficiency, it tends to perform well with respect to other views. 


\section{Discussion}

In an economic interpretation of the results, it must be emphasized that each of the three approaches is just one of ways that a researcher may look on banking business. The essence of banking production is understood in the paper from three different angles, whereas each one is linked with a particular choice of input and output variables. The distinctive features of individual treatments are summarized in Table 5 and justified in Section 2.

Table 5 | Conceptual Treatment of the Commercial Bank under the Three Approaches

\begin{tabular}{|l|l|l|l|}
\hline & \multicolumn{1}{|c|}{$\begin{array}{c}\text { Intermediation } \\
\text { approach }\end{array}$} & \multicolumn{1}{|c|}{$\begin{array}{c}\text { Service-oriented } \\
\text { approach }\end{array}$} & \multicolumn{1}{|c|}{$\begin{array}{c}\text { Profit-oriented } \\
\text { approach }\end{array}$} \\
\hline $\begin{array}{l}\text { Interpretation of the } \\
\text { bank }\end{array}$ & $\begin{array}{l}\text { a production facility } \\
\text { functioning as } \\
\text { a financial intermediary }\end{array}$ & $\begin{array}{l}\text { a service producer } \\
\text { centred at minimizing } \\
\text { cost of operations }\end{array}$ & $\begin{array}{l}\text { an entrepreneurial } \\
\text { subject seeking } \\
\text { a maximal profit }\end{array}$ \\
\hline $\begin{array}{l}\text { Dominating } \\
\text { perspective }\end{array}$ & $\begin{array}{l}\text { the macroeconomic } \\
\text { perspective }\end{array}$ & $\begin{array}{l}\text { the microeconomic } \\
\text { perspective }\end{array}$ & $\begin{array}{l}\text { the microeconomic } \\
\text { perspective }\end{array}$ \\
\hline Main beneficiary & the regulator & the customer & the shareholder \\
\hline
\end{tabular}

Source: the authors

All in all, although the technology of banking business is for every commercial bank one and only, it may be inspected and assessed from different (perhaps mutually exclusive) standpoints. The choice of a standpoint that is subsequently reflected in a particular choice of inputs and outputs depends heavily on the objectives and perspectives that are followed during the assessment. If the regulatory interest prevails, the IA is preferred; if the customer orientation is dominant, the SOA is favoured; and, finally, if the shareholders are to benefit from such an assessment, the PA is chosen. This does not challenge the fact that the bank's management endeavours to execute its strategic and operative goals. These goals that affect heavily bank's customers are frequently formulated by the management and authorized by the shareholders. In this, they receive a certain degree of regulatory supervision. Each of the three approaches is just an isolated slice throughout the entire banking business. Nonetheless, in regard to the banking condition of the Slovak Republic and from the stance of macroeconomic stability promoted by regulatory bodies, it seems possibly most rational to apply the IA, and this does not violate relevancy of the other two approaches.

As suggested in Table 5 and follows from the previous exposition, each approach answers to a different question when implemented in the DEA framework. These are for the IA, SOA and PA, respectively: (1.) Which of the banks under evaluation are efficient in financial intermediation? (2.) Which of the banks evaluated are efficient in provision of banking (both depository and credit) services? (3.) Which of the banks under analysis are efficient in attaining high profits from their operations? These questions are addressed during the evaluation of the results as presented in Table 4. A special attention is reserved to commercial banks that attain for the three evaluated sub-periods the highest efficiency scores in comparison to other banks in the area of financial intermediation, provision of services to customers and in the area of profit generation. 
The macroeconomic function of transmitting deposits into loans was during the entire period of 12 years most successfully effected in terms of highest technical efficiency by Slovenská sporitel'ňa. This largest Slovak bank by asset size that was found technically efficient in a total of 8 years from the angle of the IA. A considerable worsening of its efficiency status in 2001 is due to the reclassification and last shifts of non-standard loans from its balance sheet as part of the banking sector restructuring program. In the first three years of the second sub-period this originally retail-oriented bank recorded another decline in its comparative efficiency status of financial intermediation, which was a consequence of its attempts to increase its share in the market of corporate banking. Alongside servicing retail clientele, Slovenská sporitel'ňa reoriented on securing operational and investment financing for large enterprises in most important industries of the Slovak economy, on real estate financing, acquisition financing, syndicate loan provision and other innovative services. Although the implementation of the new business strategy focussed on expanding in the field of corporate banking impaired its capability of efficient servicing financial intermediation, the bank managed to stabilize in 2007 in this regard and to maintain technical efficiency from then. As far as wholesale banks are concerned, financial intermediation in the first two sub-periods was carried out at a comparatively high technical efficiency level by Citibank and Privat banka. It is interesting to see the trend of a decisive improvement in comparative technical efficiency in terms of financial intermediation for Poštová banka. This retail bank attained the worst efficiency scores under the IA for the first two sub-periods; however, in the last sub-period before the onset of the financial crisis it manifested full technical efficiency in comparison to other banks. Poštová banka benefits from a strategic partnership with the universal postal service provider Slovenská pošta and jointly with its subsidiary insurance companies developed a network of complex services accessible through post offices even in smallest settlement of the Slovak Republic. On the contrary, Všeobecná úverová banka (one of the three Slovak largest banks) failed in technical efficiency in the evaluated period in financial intermediation, similarly as ČSOB / Istrobanka and VOLKSBANK Slovensko. These banks were incapable of technically efficient utilization of deposits and operating cost in providing loans. In times of economic stagnation, the loan potential of the real economy is limited, and this directs to an unequivocal recommendation for these banks to decrease deposit interest rates and focus chiefly on reducing operating cost. In the case of an economic expansion, the recommendation would be related to stimulating the volume of loan contracts.

In accomplishing the microeconomic function of providing a complex of banking services, Slovenská sporitel'na was again found technically efficient, now in 10 years of the entire period of 12 years under analysis. A certain degree of technical inefficiency in providing services was found only in the first two years of the second sub-period. The reasons were catalogued earlier and apply here as well. Comparatively good technical efficiency under the SOA was attained also by Tatra banka, and an interesting pattern was observable for Všeobecná úverová banka. This bank recorded technical efficiency only in the third sub-period during the financial crisis. This position was attained by a rationalization of operating cost (that appeared on the side of inputs) and through various tactical attempts oriented on increasing the volume of granted loans and on attracting new deposit sources from clients. Among small banks under the SOA Privat banka displayed good technical efficiency; and among wholesale banks it was again Citibank and Prima 
banka that could be marked as technically efficient. Poštová banka showed the same trend of improving its efficiency status in providing banking services as in financial intermediation. In the first two sub-periods showed the worst technical efficiency out of the banks under evaluation and in the third sub-period, it became technically efficient in all three years. This concurs with the explanation given earlier. As before, VOLKSBANK Slovensko was weak in technical efficiency in providing banking services in the second and third sub-period together with OTP Banka Slovensko in the first sub-period. The recommendations for technically inefficient banks under the SOA are merely a copy of the economic policy of Všeobecná úverová banka. They rest in combining two measures: reducing operating cost and boosting up loan and deposit services attractivity.

The most heterogeneous results are attributable to the area of profit maximization. Averaging SBM efficiency scores under the PA, Slovenská sporitel'ňa showed uniformly good technical efficiency in each sub-period. Despite this, two banks were comparatively better in attaining efficiency from the perspective of profit maximization, though not in each sub-period. Privat banka displayed on average higher technical efficiency in the first two sub-periods and Všeobecná úverová banka in the last two sub-periods. The worst technical efficiency status in terms of profit maximization was revealed by OTP Banka in the first sub-period and VOLKSBANK Slovensko as well as Prima banka in the last sub-period. A fall in technical efficiency between the sub-periods is manifested by Prima banka, whose average technical efficiency decreased during the sub-periods. This development may easily be argued by considerable financial losses during the financial crisis. It is possible to phrase some policy recommendations for improving profit-oriented technical efficiency. They lie in decreasing operating cost and in increasing net interest income. It is self-evident that this strategy may be applied only temporarily. This is the reason why there is no bank in the analysed group of commercial banks subdued to analysis that would be able to persevere in technical efficiency in terms of the PA for a longer period of time.

In summing up and comparing the results across the individual approaches, one commercial bank appears to report a very satisfactory status of technical efficiency under each approach and it is Slovenská sporitel'na. In spite of the fact that there is evidence of its banking operations being comparatively most efficient under each approach, there is some room for improvement on its efficiency in terms of profit maximization. As opposed to Slovenská sporitel’ňa, VOLKSBANK Slovensko was found least technically efficient almost uniformly with each of the three approaches whose situation was later translated into a change in ownership. The most dynamic changes were typical of Poštová banka, which finally achieved a good efficiency status in the third sub-period under each approach. The efficiency level of Poštová banka in the third sub-period in terms of financial intermediation, provision of services and profit maximization was comparable to that of Slovenská sporitel'ňa. In a similar manner, it is possible for individual commercial banks to identify and state the qualitative aspects of their banking operations - whether they may be deemed technically (in)efficient in terms of financial intermediation, provision of services and profit maximization. Still, it is always a particular view of the same production technology of commercial banks. 


\section{Conclusions}

The paper contributed both to the methodology of technical efficiency evaluation of commercial banks and to the empirical research on the efficiency of the Slovak banking sector. Three competitive theoretic approaches that had been developed for commercial banks - the intermediation approach, the service-oriented approach and the profit-oriented approach - were considered in the paper and under them commercial banks of the Slovak banking sector over the years 2000-2011 were evaluated in terms of technical efficiency that they had exhibited in their operations. In the evaluation, a non-parametric SBM model was applied under two crucial assumptions. The assumption of variable returns to scale is one of classical assumptions made in such analyses, and this assumption was supplemented here by the requirement that the production frontier remain constant in three identified sub-periods (phases) in the evolution of the Slovak banking sector: 2000-2003, 2004-2008 and 2009-2011. In each of these sub-periods, commercial banks of the Slovak banking sector were pooled in one data frame, from which the information on the shape of the production frontier (constant in individual sub-periods and common to all commercial banks in the given sub-period) was extracted by the SBM model in the form of SBM technical efficiency scores. These were subject to comparisons so as to ascertain whether the choice of the theoretic approach may influence the final view of the efficiency status of individual commercial banks. The finding is that commercial banks that appear comparatively technically efficient under one approach were usually discovered technically efficient with respect another approach. This is owing to a wide variety of banking goals that include goals of macroeconomic essence as well as those of microeconomic essence, and commercial banks strive to fulfil all their goals simultaneously, which affects their efficiency status.

Possible differences in the results are but a natural consequence of adopting a specific standpoint in interpreting the ultimate goal and principal function of commercial banks. One should be cautious in applying any approach that it is just a slice throughout manifold goals and functions that commercial banks pursue. These three approaches should not be deemed as conflicting but complementary in interpreting aspects of banking business. A commercial bank may perform differently in financial intermediation, provision of banking services and profit seeking. In recognition of this diversity, the study clarifies this issue and provides methodological notes to financial market regulators, commercial banks' management and shareholders that are useful in measuring technical efficiency of banking businesses. In addition, it provides information for these interested parties on the technical efficiency status of Slovak commercial banks from the perspective of the three approaches and gives an insight into how technically efficiently individual commercial banks employed their inputs in producing their desired outputs in the period of the past 12 years. 


\section{References}

Ahn, H., Le, M. H. (2014), "An Insight into the Specification of the Input-Output Set for DEA-Based Bank Efficiency Measurement." Management Review Quarterly. Vol. 64, No. 1, pp. 3-37, http://dx.doi. org/10.1007/s11301-013-0098-9

Banker, R. D., R. F. Charnes, Cooper, W. W. (1984), "Some Models for Estimating Technical and Scale Inefficiencies in Data Envelopment Analysis." Management Science. Vol. 30, No. 9, pp. 1078-1092, http://dx.doi.org/10.1287/mnsc.30.9.1078

Benston, G. (1965), "Branch Banking and Economies of Scale.” Journal of Finance. Vol. 20, No. 2, pp. 312-331, http://dx.doi.org/10.1111/j.1540-6261.1965.tb00212.x

Berger, A. N., Hanweck, G. A., Humphrey, D. B. (1987), "Competitive Viability in Banking: Scale, Scope and Product Mix Economies." Journal of Monetary Economics. Vol. 20, No. 3, pp. 501-520, http://dx.doi. org/10.1016/0304-3932(87)90039-0

Berger, A. N., Humphrey, D. B. (1997), “Efficiency of Financial Institutions: International Survey and Directions for Future Research." European Journal of Operational Research. Vol. 98, No. 2, pp. 175-212, http://dx.doi.org/10.1016/S0377-2217(96)00342-6

Charnes, A, Cooper, W. W., Rhodes, E. (1978), "Measuring the Efficiency of Decision Making Units." European Journal of Operational Research. Vol. 2, No. 6, pp. 429-444, http://dx.doi. org/10.1016/0377-2217(78)90138-8

Grigorian, D., Manole, V. (2002), “Determinants of Commercial Bank Performance in Transition: An Application of Data Envelopment Analysis." Working Paper No. 146. Washington: International Monetary Fund.

Hancock D. (1991), A Theory of Production for the Financial Firm. Norwell: Kluwer Academic Publishers.

Kamecka, M. (2010), "Bank Efficiency in CEE." Doctoral thesis, WU Vienna University of Economics and Business.

Kenjegalieva, K. A., Simper, R., Weyman-Jones, T. G. (2009), “Efficiency in Transition Banks: Inter-Country Banking Industry Trends." Applied Financial Economics. Vol. 19, No. 19, pp. 1531-1546, http://dx.doi. org/10.1080/09603100902984343

Oh, D. H., Suh, D. (2013), "Nonparaeff: Nonparametric Methods for Measuring Rfficiency and Productivity." R package, Version 0.5-8 of 2013-02-22, http://cran.r-project.org/web/packages/ nonparaeff/index.html

R Core Team (2013), R: A Language and Environment for Statistical Computing. Vienna: R Foundation for Statistical Computing, http://www.r-project.org/.

Sealey, C. W., Lindley, J. T. (1977), "Inputs, Outputs and a Theory of Production and Cost at Depository Financial Institutions." Journal of Finance. Vol. 32, No. 8, pp. 1251-1266, http://dx.doi. org/10.1111/j.1540-6261.1977.tb03324.x

Stavárek, D., Řepková, I. (2012), "Efficiency in the Czech Banking Industry: A Non-Parametric Approach.” Acta Universitatis Agriculturae et Silviculturae Mendeleianae Brunensis. Vol. LX, No. 2, pp. 357-366.

Stavárek, D. (2006), "Banking Efficiency in the Context of European Integration." Eastern European Economics. Vol. 44, No. 4, pp. 5-31.

Tomova, M. (2006), "X-efficieny of European Banking - Inequality and Convergence." Free University of Brussels.

Tone, K. (2001), "A Slacks-Based Measure of Efficiency in Data Envelopment Analysis." European Journal of Operational Research, Vol. 130, No. 3, pp. 498-509, http://dx.doi.org/10.1016/S0377-2217(99)00407-5

Vincová, K. (2006), “Neefektívnost’ z rozsahu v bankovom sektore. Komparácia slovenského a českého bankového sektora." Národná a regionálna ekonomika VI, Herlany. Košice: Technická univerzita, pp. 440-445.

Wozniewska, G. (2008), "Methods of Measuring the Efficiency of Commercial Banks: An Example of Polish Banks." Ekonomika. No. 84, pp. 81-91.

Zemanová, V. (2007), "Aplikácia metódy DEA na bankový sektor Slovenskej republiky." Proceedings from the conference AIESA Mladá veda. Bratislava: Ekonóm. 